\title{
INFORMATION TECHNOLOGY AND MARKET ORIENTATION ON THE COMPETITIVENESS AND PERFORMANCE OF A KUNINGAN'S TOURISM ACTIVITY
}

\author{
Wely Hadi Gunawan*, Wachyuni \\ Universitas Kuningan, Indonesia
}

\begin{abstract}
ABSTRACT: Kuningan local tourism possesses a promising future. However, some investigations cite a decrease in visitors over time, revealing underlying problems in the organization. Critical inquiries may arise from the interaction of information technology and market orientation to increase competitiveness and, finally, tourist attractions' performance. Thus, this study investigates the local tourism activity of Panembongan Hill in Kuningan, Banten, Indonesia. One hundred thirty visitors agree to participate in the study, and the coded responses are analyzed using structural equation modeling. The results reveal that Information Technology does not relate to competitiveness and tourism business performance; market orientation increases competitiveness and business performance. Finally, the competitiveness of tourism activities propels business performance considerably.
\end{abstract}

Keywords: Information Technology, Market Orientation, Competitiveness, Business Performance, Tourism Activities

*Corresponding author: welyhadigunawan@uniku.ac.id

DOI: $10.24252 /$ minds.v7i2.16379

ISSN-E: 2597-6990

ISSN-P: 2442-4951

http://journal.uin-alauddin.ac.id/index.php/minds 


\section{INTRODUCTION}

Kuningan Regency Government aggressively promotes various existing tourist attractions as an effort to increase regional income. The government continues to improve itself in making changes to meet consumer needs by maintaining local wisdom. The development of tourist attractions needs to prepare a digital-based database to increase tourist promotion and visits. Tourist attractions must also have supporting facilities such as hotel accommodation, restaurants, souvenirs, transportation in tourist attractions. One of the tourist attractions in Kuningan Regency is Panembongan Hill in Tembong village, district Garwangi, Kuningan regency, Indonesia. It is located at an altitude of \pm 600 AMSL, with fresh air and beautiful scenery to please the visitors' eye. Marketing tourism activities become the main agenda of the local government and managers. Every manager, including the Panembongan tourism object, must envision the market trend, customer needs, and business environment changes related to other competitors.

One of them is to improve the existing aspect like the quality of information technology to penetrate competitors by distinguishing business results (Cakmak \& Tas 2012). Information technology makes it easy for consumers to access all information whenever and wherever they are. Companies can also monitor business competitors' activities and change strategies created by businesses similar to theirs. Nowadays, the use of information technology by tourists is widely used because information technology is one factor that influences the success of a company's new product by creating new products that are more innovative and better. The technology most commonly used by tourists is internet information technology. Law \& Bai (2010) emphasized this development, which states that tourists can facilitate access to information about tourism products without being hindered by distance and time with the internet.

Many studies explain that market orientation is crucial in creating and maintaining its competitive advantage. Market orientation is defined as the company's response to customer needs and tastes (Narver \& Slater, 1990). In increasingly fierce and dynamic competition conditions, the company must continue to innovate on its products and services because if it does not adapt quickly, the company will be left behind and unable to compete. Hartini (2017) defines market orientation as the organizational culture that leads to the market and states that market orientation is an antecedent variable of competitive advantage and company performance. A good organization is an organization capable of improving the organization's capabilities or expertise. The company's performance is an achievement achieved by the business that can be seen from the results. This performance result is not correct when viewed from only one dimension. The researchers agreed that measuring business performance was not enough to use one measure (Day \& Wensley, 1998; Jaworski \& Kohli, 1993). In Jaworski and Kohli (1993) and Chang (1998) research, the company's performance was measured by overall business performance compared to last 
year and overall performance compared to its main competitors, while in Slater and Narver (2000) research, it is measured by profitability compared to targets that have good organizational performance. If the company becomes a market leader, this shall be supported by a persistent attitude, under quality standards, and businesses that lead to overpressure style mostly do not survive (Veerendrakumar \& Shivashankar, 2015). Excellent business performance ultimately results in maximum work and then generates competitiveness for the company. The achieved competitiveness must be maintained as more competitors are paying attention to where the company is off guard; therefore, the company must preserve its excellence in a sustainable manner (Russell \& Millar, 2014). Competitiveness can be created if various components' synergy works well by their competencies (Waheed et al., 2013). The purpose of this research is to investigate and analyze the influence of information technology on competitiveness, market orientation on competitiveness, the influence of information technology on business performance, market orientation on business performance, and the influence of competitiveness on business performance.

\section{LITERATURE REVIEW}

\section{Information Technology}

Information is the process of exchanging data and messages without restrictions of space and time. Information technology is also defined as a different set of tools including hardware, information theory, data networks, work stations and artificial intelligence (robotics), that the use of this information is a systematic process used to conduct an activity (Aslizadeh, Ahmad, 2014). The competence of information technology adds value to customers. Information technology capabilities focus on internal efficiency and reduce unnecessary costs. This stance leads to a change in information technology capabilities that are significantly integrated into the value chain (Vogel, 2005). Gareau (2004) argues that information technology is a potential tool in combating and assisting people's needs. Therefore, information technology is the best tool for detecting problems in society. The competence of information technology has an external focus on added value for customers. Information technology capabilities focus on internal efficiency and reduce unnecessary costs, leading to a change in information technology capabilities that significantly integrated the value chain (Vogel, 2005).

\section{Market Orientation}

The company's market-oriented market orientation is the company that makes customers a top priority for the company to run its business. According to Kohli \& Jaworski (1990), the market's orientation is defined as gathering market intelligence to meet current and future customers' needs. Narver and Slater (1990: 21) define market orientation as the most effective organizational culture in creating essential behaviors for creating superior value for buyers and performance in business. 


\section{Competitiveness}

In creating competitiveness in business, companies must have the ability to exploit, address specific problems as capabilities grow over time, utilize and create new resources, such as skills (through new technologies or software applications), or open up new types of development opportunities. The company is said to have a competitive advantage when implementing value creation strategies to produce professional personnel. Lastly, superior performance results and excellence in production reflect competitive advantage (Agha, 2012). The company creates competitiveness through competitive capabilities or priorities defined as preferences or strategic dimensions in which the company chooses to compete in the targeted market. Many competitive priorities are identified in the literature as a favorable position against movement (dynamic), a homogeneous advantage over heterogeneous advantage, a real advantage over unreal advantage, a simple advantage compared to combined (accumulated) advantage (Russel, 2014).

\section{METHODOLOGY}

This study investigates the visitors whose number is indefinite in local tourism activity in Kuningan, West Java, Indonesia, famously known as Panembongan Hill (Ferdinad, 2006). This study's sample was 130 visitors who came to Panembongan tourism, from domestic and foreign tourists. The primary data is collected using questionnaires related to information technology, market orientation, competitiveness, and business performance. This research uses the following data collection techniques: surveys, observations, and questionnaires. The data analysis in this study used The Structural Equation Modeling (SEM) of the AMOS 2.1 statistical software package in a hypothetical assessment model. Structural equation model (SEM) is a statistical technique that allows testing a series of relatively "complicated" relationships simultaneously (Hair et al., 1995).

\section{RESULTS}

This research uses Structural Equation Modeling (SEM) that demands several criteria, namely, evaluating conformity criteria for testing the model feasibility index (goodness of fit). The processing results in the analysis of confirmation factors of Information Technology and Innovation show that all indicators used to form this research model have met the standard. Table 1 displays the finding as all values of Chi-Square, CFI, TLI, CMIN/DF, and RMSEA are within the required range. Thus, the construction used to form the research model has met the model feasibility criteria. The model hypothesis test indicates that this model corresponds to the data. Table 1 summarizes the goodness of fit test. 
Table 1. Summary of Goodness of Fit Index

\begin{tabular}{cccc}
\hline Criteria & Cut-off Value & Analysis Results & $\begin{array}{c}\text { Model } \\
\text { Evaluation }\end{array}$ \\
\hline Chi-Square & Small is expected & 59,066 & Good \\
Significant Probability & $\geq 0.05$ & 0,131 & Good \\
GFI & $\geq 0.90$ & 0,927 & $\begin{array}{c}\text { Good } \\
\text { Marginal }\end{array}$ \\
AGFI & $\geq 0.90$ & 0,882 & \\
& & & \\
TLI & $\geq 0.95$ & 0,981 & Close \\
CFI & $\geq 0.95$ & 0,986 & Close \\
RMSEA & $\leq 0.08$ & 0,042 & Close \\
\hline
\end{tabular}

Source: AMOS output

The hypothesis is derived and tested by statistical test in path analysis. Statistical tests of processing results with SEM are carried out by looking at the significance level of the relationship between the variables indicated through the Probability (p) and Critical Ratio (CR) values, respectively. The statistical evidence reveals the ability of each indicators represent the respected variables in table 2.

Table 2. Standardized Regression Weight

\begin{tabular}{lllr}
\hline Items & & Constructs & Estimate \\
\hline X1 & $<---$ & Information_Technology &, 812 \\
X2 & $<---$ & Information_Technology &, 835 \\
X3 & $<---$ & Information_Technology &, 730 \\
X6 & $<---$ & Market_Orientation &, 753 \\
X5 & $<--$ & Market_Orientation &, 777 \\
X4 & $<---$ & Market_Orientation &, 808 \\
X9 & $<---$ & Competitiveness &, 828 \\
X8 & $<---$ & Competitiveness &, 927 \\
X7 & $<---$ & Competitiveness &, 844 \\
X12 & $<---$ & Business_Performance &, 735 \\
X11 & $<---$ & Business_Performance &, 796 \\
X10 & $<---$ & Business_Performance &, 895 \\
\hline \multicolumn{3}{c}{ Source: SEM-AMOS Output }
\end{tabular}

After all the assumptions have been met, the hypothesis testing will be carried out as proposed in the previous chapter. Testing the five hypotheses of this study was carried out based on the Critical Ratio (CR) value of a causal relationship from SEM processing results as in table 3 and figure 1. 
Table 3. Regression Weight Structural Equational Model

\begin{tabular}{lcccc}
\hline The path relationships & Estimate & S.E. & C.R. & P \\
\hline Information Technology $\rightarrow$ Competitiveness &, 016 &, 128 &, 125 &, 900 \\
Market Orientation $\rightarrow$ Competitiveness &, 703 &, 162 & $4,331,000$ \\
Information Technology $\rightarrow$ Business Performance &,- 026 &, 108 & -238 &, 812 \\
Market Orientation $\rightarrow$ Business Performance &, 433 &, 154 & 2,805 &, 005 \\
Competitiveness $\rightarrow$ Business_Performance &, 267 &, 094 & 2,829 &, 005 \\
\hline
\end{tabular}

Source: SEM-AMOS output

The calculation result obtains the $\mathrm{CR}$ from information technology to competitiveness is 0.125 , with a probability of 0.900 greater than 0.05 . This value indicates that information technology does not affect competitiveness, so H1 is rejected. The results of this study showed that information technology does not improve the competitiveness of Panembongan tourist attractions. The calculation result obtained by CR from market orientation to competitiveness is 4,331, with a probability of 0.000 being less than 0.05 . This score indicates that market orientation has an influence on competitiveness, so $\mathrm{H} 2$ is accepted. The results of this study show that market orientation will improve the competitiveness of Panembongan tourist attractions.

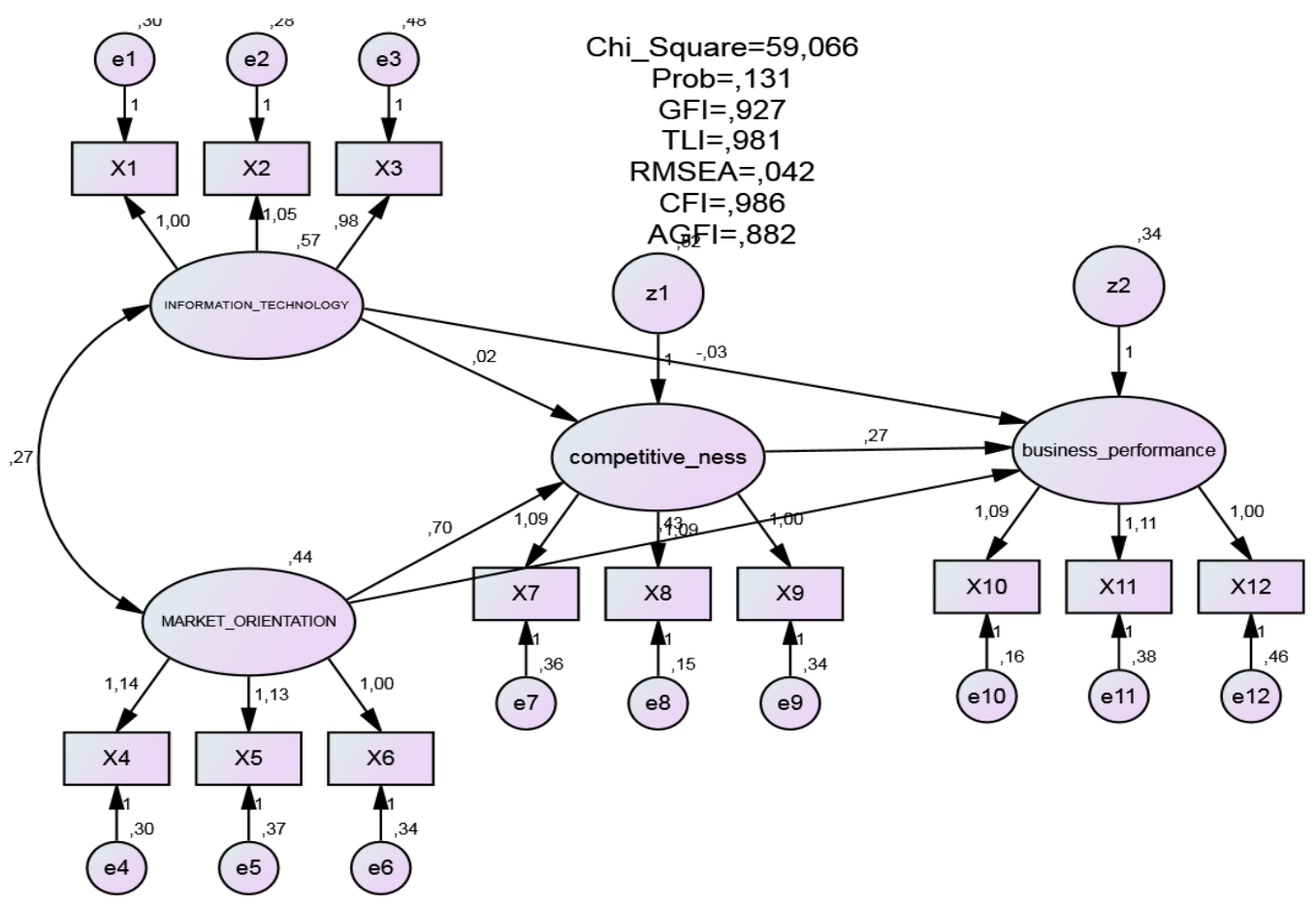

Figure 1. Causal Relationships

The calculation result obtained by CR from information technology to business performance is -0.238 with a probability of 0.812 , more significant than 0.05 . This finding indicates that information technology has no effect on business performance, so H3 is rejected. This study showed that the high information technology of tourist attractions does not improve Panembongan tourism objects' 
business performance. The calculation result obtained from cr market orientation to business performance is 2,805 with a probability of 0.005 less than 0.05 . This score indicates that market orientation has an effect on business performance, so $\mathrm{H} 4$ is accepted. The results of this study show that the market orientation at Panembongan tourism object will improve business performance. The calculation result obtained from CR is 2.829 with a probability of 0.005 , which is less than 0.05, indicating that high competitiveness affects business performance, so H5 is accepted. This study shows that the high competitive advantage of Panembongan tourist attraction will improve business performance.

\section{DISCUSSION}

This study reveals several interesting findings. Information technology in Panembongan tourism village does not affect competitiveness, confirming the previous result of Samsiah, Marlina, Ardi (2018), and Cakmak (2012) that information technology does not affect competitive advantage. Tourism information technology is usually only used to create technical and economic effects, not part of the strategy. Nevertheless, it should be noted that companies need information technology to be able to have competitiveness. Information technology has a role in increasing human resource productivity in exploring, controlling, and developing natural resources to improve competitiveness in the market (LIPI, 1993). Information technology is used to produce, process, and disseminate information to increase guest visits (Nustini, 2003).

High market orientation influences the competitiveness of Panembongan tourism objects. The better the market orientation, the higher the competitiveness of Panembongan tourism objects. Conversely, the market's orientation is low; the competitiveness of Panembongan hill tourism will also be lower. Research conducted by Supranoto (2009) that market orientation has a positive effect on competitiveness. Panembongan tourist attractions, when doing market orientation, can compete with tourist attractions in Kuningan Regency. Information technology on business performance information technology does not affect business performance in Panembongan tourism object. This research is in line with Febrian (2019), which shows that information technology has a low impact on Indonesia's tourism business performance. Businesses without utilizing information technology can suffer setbacks and stops, so organizations leverage technology to support sustainability and increase corporate profits. Information technology can help business performance, information technology related to speed and accuracy because what was previously done manually is replaced by programs or systems that make processing time short and easy.

Information technology concerning business performance has a set of elements that support the realization of better business performance. The 
manager of Panembongan may facilitate the work of information management systems to affect the speed, accuracy, and accuracy in working to maximize business performance. It is far from the picture because they still rely on human capabilities and not yet on technology. This research concurs with Wahirayasa and Kusuma (2018) that the market orientation carried out by tourism managers affects business performance. Han et al. (1993) point out that market orientation is a business culture where organizations are committed to being creative in creating superior value for customers. Narver and Slater (1990, p.21) define market orientation as the most effective organizational culture in creating behaviors essential to creating superior value.

Business performance is a measure of the company's success measured over a predetermined time. The result is supported by Riyanto (2018) that competitiveness affects business performance. The results of this research are also in line with the theory put forward by Ferdinand (2000) and Porter (1985) that competitiveness can be generated if the company succeeds in building, maintaining, and developing various specific advantages of the company as a result of the operation of various strategic assets owned and developed by the company. Competitiveness is also generated because of the resources and competencies that become the company's potential source. The company creates excellence by strategic selection to compete in a targeted market.

\section{FURTHER STUDY}

First, information technology does not affect competitiveness. In the future, Panembongan tourism object is expected to reap benefits from information technology, mobile phones, and internet network connections in order to be able to convey the information needed by tourists so that it can compete to increase the number of visitors. Second, Market orientation influences competitiveness. Panembongan tourism object expectations must always increase customers' value as an influential organizational culture to create competitiveness for buyers and perform business. Third, Information technology does not affect business performance. Enhanced information technology is used for tourist attraction management, but it has no direct effect on business performance. Fourth, Market orientation affects business performance. In this case, Panembongan tourist attractions may focus on tourists, competitors, and building a thriving business culture. Fifth, competitiveness influences business performance. We recommend that the competitiveness strategy focuses on building good cooperation of tourism object managers with Perum Perhutani KPH Kuningan and Forest Village Community Institute (LMDH) and Tembong Village with Collaborative Forest Management System (PHBM) pattern, establish stakeholder relationships, and utilize and develop natural resources to the maximum. 


\section{REFERENCES}

Abdi, A.M., Yassin, A. \& Ali, S. (2013). Innovation and Business Performance in the Telecommunication Industry in Sub-saharan African Context: Case of Somalia. Asian Journal Of Management Sciences E Education. Vol. 2, No. 4, pp.53-67.

Aslizadeh, A. (2014). Impact of Using Information Technology on Creating a Sustainable Competitive Advantage for Companies; ( Case study: Golestan Food Companies ). Indian Journal of Fundamental and Applied Life Sciences, Vol. 4, pp.1595-1603.

Associate, S.A. (2012). Effect of Core Competence on Competitive Advantage and Organizational Performance. International Journal of Business and Management, Vol.7, No.1, pp.192-205.

Baker and Sinkula. (2005). Product Innovation Management. Journal of MarketFocused Management

Cakmak, P.I. \& Tas, E. (2012.). The Use of Information Technology on Gaining Competitive Advantage in Turkish Contractor Firms. World Applied Sciences Journal, Vol. 18, No. 2, pp.274-285.

Chang T.Z and Chen S.J. (1998). Market orientation, service quality, and business profitability: a conceptual model and empirical evidence, Journal of Service Marketing, Vol. 12, p. 246-264.

Clarismary, O.C. (2015). Change in Information Technology and Organizational Performance: a study of Consolidated Hallmark. International Journal of Management and Commerce Innovations, Vol. 3, No. 1, pp.579-587.

Day, G. S. \&Wensley, R. (1998). Assessing Advantage: Diagnosing Competitive Superiority. Journal of Marketing, 52(2): 1-20

Dirisu, J.I. \& Ibidunni, O.S. (2013). Product Differentiation: a Tool of Competitive Advantage and Optimal Organizational Performance (a Study of Unilever Nigeria PLC ). European Scientific Journal, Vol. 9, No. 34, pp.258-281.

Eruemegbe, G.O. (2015). Effect of Information and Communication Technology on Organization Performance in The Banking Sector. International Journal of Research in Engineering \& Technology (IMPACT: IJRET), 3(4), pp.13-22.

Ferdinand, Augusty,. (2006). Metode Penelitian Manajemen. Edisi 2. Penerbit Universitas Diponegoro, Semarang.

Ferdinand, A. T. (2014). Structural Equation Modeling. BP UniversitasDiponegoro, Semarang.

Gareau, S.E. (2004). The development of guidelines for implementing information technology to promote food security. pp.273-285.

Gunawan, W. H. (2018). Faktor-faktor Keunggulan Bersaing dan Implikasi Terhadap Kinerja Perusahaan. Indonesian Journal of Strategic Management, Vol 1, No 2

Ghozali, I. (2011). AplikasiAnalisis Multivariate dengan Program IBM SPSS 19. Badan Penerbit Universitas Diponegoro.

Hair, J.F., Jr., R.E. Anderson, R.L., Tatham \& W.C. Black. (1995). Multivariate Data Analysis With Reading., Englewood Cliffs, NJ: Prentice-Hall. 
Hamali . S, Hidayat .C and Darman. (2017). Pengaruh Dimensi Inovasi terhadap Kinerja Pemasaran dan Keuangan pada Industri Kecil Pakaian Rajutan Binong Jati Jawa Barat. Banking and Management Review, 6 (1), 790-801

Hana, U. (2013). Competitive Advantage Achievement through Innovation and Knowledge. Journal of Competitiveness. Vol. 5, No. 1, pp.82-96.

Ibrahim, A.R. (2009). The Relationship of Intellectual Capital, Innovation and Organizational Performance: a Preliminary Study in Malaysian SMEs", International Journal of Management Innovation Systems, Vol. 1, No. 1, pp.113.

Jersone, B. et al. (2013). Does an Innovation Process Improve. Vol. 13, No. 5

Kohli, A.K. \& Jaworski, B.J. (1990). Market Orientation: The Construct, Research Propositions, And Managerial Implications. Journal Of Marketing,

Lumpkin, G. T. \& Dess, G. G. (1996). Clarifying The Entrepreneurial Orientation Construct And Linking It To Performance. Academy Of Management Review, 21(1)

Jaworski, Bernard J., and Ajay K. Kohli. (1993). Market Orientation: Antecedents and Consequences, Journal of Marketing. 57 (July): 53 - 70

Koi-akrofi, G.Y. et al. (2011). Information Technology Investments and Organizational Performance of the Telecommunications Industry in Ghana. Journal of Information Technology, Vol. 3, No. 3, pp.118-132.

Ling, L.S., Tee, O.P. \& Eze, U.C. (2013). The Effects of Information Technology Applications on Collaborating Capability in Achieving Organisational Competitive Advantages. International Journal of Business and Management, Vol. 8, No. 13, pp.1-15.

Majeed, S. (2011). The Impact of Competitive Advantage on Organizational Performance. International Journal of Business and Management, Vol.3, No. 4, pp.191-197.

Meike. (2009). Strategi Menciptakan Keunggulan Bersaing Produk Melalui Orientasi Pasar, Inovasi, Dan Orientasi Kewirausahaan Dalam Rangka Meningkatkan Kinerja Pemasaran (Studi Empiris Pada Industri Pakaian Jadi Skala Kecil Dan Menengah Di Kota Semarang), Tesis, Universitas Diponegoro

Lenssen, G., Bevan, D., Fontrodona, J., Minoja, M., Zollo, M., \& Coda, V. (2010). Stakeholder cohesion, innovation, and competitive advantage. Corporate Governance: The international journal of business in society.

Moghavvemi, S. (2012). Competitive Advantages Through its Innovation Adoption by SMEs. Journal Social Technologies, Vol. 7564, No. 1, pp.24-39.

Muafi \& Roostika, Ratna. (2014). Organizational Performance and Competitive Advantage Determinants of Creative SMEs. European Journal Of Economics And Management, Vol. 1, No. 2, pp.7-25

Narver, J.C., \&Slater, S.F. (1990). The Effect of Market Orientation on Product innovation. Journal of Marketing. P.20-35.

Nustini, Y. (2003). Dupont Analysis of an Information Technology. JAAI, Vol. 7, No. 2, pp.139-158.

Ofori, D. et al. (2015). Innovation and Knowledge Sharing: a New Competitive 
Advantage in the Mobile Telecommunication Industry in Ghana. Science Journal of Business and Management. Vol. 3, No. 5, pp.157-163.

Olusola, A. \& Oluwaseun, Y. (2013). An Appraisal of the Impact of Information Technology ( IT ) on Nigeria Small and Medium Enterprises (SMEs) Performance, International Journal of Academic Research in Management (IJARM), Vol. 2, No. 4, pp.140-152.

Porter, M.E. (1985). Competitive Advantage: Creating and Sustaining Superior Performance: With a new introduction.

Rianto S. (2018). Analisis Pengaruh Lingkungan Internal dan Eksternal terhadap Keunggulan Bersaing dan Kinerja Usaha Kecil Menengah (UKM) di Madiun. Jurnal manejemen bisnis dan inovasi. Vol. 5, No. 3,pp.159-167

Ringim, K.J., Razalli, M.R. \& Hasnan, N. (2012). Moderating effect of Information technology (IT) capability on the relationship between business process reengineering factors and organizational performance of Bank. Journal of Business Management, Vol. 6, No. 16, pp.5551-5567.

Rusdi, J.F. (2019). Peran Teknologi Informasi pada Pariwisata Indonesia", Jurnal Accounting Information System, Vol. 2, No.2,pp.78-118

Russell, S.N. \& Millar, H.H. (2014). Exploring the Relationships among Sustainable Manufacturing Practices, Business Performance, and Competitive Advantage: Perspectives from a Developing Economy. Journal of Management and Sustainability, Vol. 4, No. 3, pp.37-54.

Sciences, M. et al. (2011). Gaining Competitive Advantage and Organizational Performance through Customer Orientation. Innovation, Differentiation. Vol. 1, No. 5, pp.80-91.

Setyawati, A. (2014). Effect of Strategic Decision, Innovation, and Information Technology Adoption on Competitive Advantages and MSME Performance Studies at MSME Food and Beverage Industry Sector in Bandung Raya. Europan Journal Business and Management, Vol. 6, No. 35, pp.52-58.

Sharma, M.K. \& Bhagwat, R. (2006). Performance measurements in the implementation of information systems in small and medium-sized enterprises: a framework and empirical analysis", Measuring Business Excellence, Vol. 10, No. 4, pp.8-21.

Setyawati \& Rosiana. (2015). Inovasi dan Keunggulan Kompetitif sebagai Variabel Mediasi Pengaruh Orientasi Pasar Terhadap Kinerja BIsnis (studi empiris pada Usaha Kecil dan Menengah di Purwokerto). Jurnal Fokus Bisnis, Vol. 5, No 01.

Setyawati, H.A. (2013). Pengaruh Orientasi Kewirausahaan dan Orientasi Pasar terhadap Kinerja Perusahaan melalui Keunggulan Bersaing dan Persepsi Ketidakpastian Lingkungan sebagai Prediksi Variabel Moderasi (survey pada UMKM Perdagangan di Kabupaten Kebumen). Jurnal Fokus Bisnis, Vol. 12, No. 02.

Soliman, F. (2013). Does Innovation Drive Sustainable Competitive Advantages?. Measuring Business Excellence. Vol. , 9, No. 1, pp.130-143.

Tintin S. (2018). Pengaruh Strategi Inovasi terhadap Keunggulan Bersaing di 
Industri Kreatif (Studi Kasus UMKM Bidang Kerajinan Tangan di Kota Bandung). Jurnal Riset Bisnis dan Investasi. Vol. 4, No. 1

Tachiki, D., Hamaya, S., \& Yukawa, K. (2004). Diffusion and Impacts of the Internet and E-Commerce in Japan.

Ugi T. Maya S. (2019). Pengaruh Usaha Minuman Thai Tea Di Kota Bandung. Proceeding Polban

Veerendrakumar, M. \& Shivashankar, K. (2015). Economics and Management Sciences Exploratory Study on Achieving Sustainable Competitive Advantage through Supply Chain Innovation for Strengthening Organizational Performance. International Journal of Economics and Management Sciences. Vol. 4, No. 3, pp 1-6.

Vogel, M. A. (2005). Leveraging InformationTechnology Competencies and Capabilities for a Competitive Advantage. pp 1-197

Waheed, H., Qureshi, T. M., Khan, M. A., \& Hijazi, S. T. (2013). The mediating role of knowledge sharing: Organizational performance for competitive advantage and innovation. African Journal of Business Management, 7(7), 536-547.

Wahirayasa, C. G., \& Kusuma, A. G. A. A. Peran E-marketing dalam Memediasi Pengaruh Orientasi Pasar terhadap Kinerja Bisnis. E-Jurnal Manajemen Universitas Udayana, 7(6).

Walker, R. M., Damanpour, F., \& Devece, C. A. (2011). Management innovation and organizational performance: The mediating effect of performance management. Journal of Public Administration Research and Theory, 21(2), 367-386. 